\title{
Loneliness dan Internalizing Problems Remaja
}

\author{
Khofifah Nur Sabrina ${ }^{1}$, Nandy Agustin Syakarofath ${ }^{2}$, \\ Diah Karmiyati ${ }^{3}$, Dian Caesaria Widyasari ${ }^{4}$ \\ ${ }^{1234}$ Fakultas Psikologi, Universitas Muhammadiyah Malang \\ Jl. Raya Tlogomas No. 246 Malang - Jawa Timur 65144. \\ nandysyakarofath@umm.com
}

\begin{abstract}
Abstrak
Loneliness yaitu keadaan seseorang yang menginginkan kehadiran orang lain tetapi tidak terpenuhi. Remaja yang memiliki perasaan kesepian yang berkepanjangan dan tidak diatasi maka akan semakin besar remaja melakukan gejala Internalizing problems. Internalizing problems adalah sebuah penghayatan seseorang dalam menghadapi masalah ke dalam diri secara berlebihan. Sehingga terjadi gejala depresi, kecemasan, penarikan sosial terhadap seseorang. Tujuan dari penelitian ini untuk mengetahui hubungan loneliness dan internalizing problems pada remaja. Penelitian ini merupakan penelitian kuantitatif non-eksperimen dengan teknik simple random sampling dan jumlah sampel pada penelitian ini sebanyak 616 orang. Kriteria penelitian ini adalah remaja berusia 15-18 tahun dan berdomisili di Jawa Timur. Skala yang digunakan adalah UCLA Loneliness Scale Version 3 dan Strength \& Difficulties Questionnaire (SDQ). Hasil penelitian menunjukkan adanya hubungan positif yang signifikan antara Loneliness dan Internalizing Problems ditandai dengan nilai $\mathrm{r}=0,618, \mathrm{p}=0,000$, yang berarti semakin tinggi tingkat Loneliness pada seseorang maka semakin tinggi pula tingkat Internalizing Problems yang dimilikinya.
\end{abstract}

Kata Kunci : Remaja, Internalizing problems, Loneliness.

\begin{abstract}
Loneliness is a state when someone wants a presence of another person but is not fulfilled. Adolescents who has prolonged and unresolved loneliness will be more likely to experience internalizing problems. Internalizing problems occur when a person vivify their problems internally excessively. Symptoms of internalizing problems are depression, anxiety, and social withdrawal towards someone. The purpose of this study is to determine the relationship of loneliness and internalizing problems. This research is a non-experimental quantitative research with simple random sampling technique with subjects totaling 616 people. The criteria of the subject were adolescents aged 15-18 years and domiciled in East Java. The scales used were the UCLA Loneliness Scale Version 3 and the Strength \& Difficulties Questionnaire (SDQ). The results showed that there was a significant positive relationship between loneliness and internalizing problems $r=0.618, p=0.000$, which means a the higher the level of loneliness in a person, the higher the level of internalizing problems one will has.
\end{abstract}

Keywords: Adolescence, Internalizing problems, Loneliness.

\section{PENDAHULUAN}

Pada masa remaja, percepatan pertumbuhan terjadi dalam beberapa domain, mulai dari fisik, otak dan penalaran maupun dengan seksualitas (Swartz, 2012; Santrock, 2011). Berbagai perubahan pada masa ini mengakibatkan adanya permasalahan pada remaja. Masalah yang dihadapi salah satunya internalizing problems yaitu masalah yang signifikan, persisten, dan merusak fungsi sosial dan sekolah. Secara epidemiologis dan klinis menunjukkan gangguan ini dapat menjadi upaya peningkatan risiko upaya bunuh diri, penggunaan alkohol, dan depresi (Scaini, Palmiera, \& Caputi, 2018). Internalizing problem umumnya dianggap sebagai sub psikopatologi yang melibatkan gangguan emosi atau suasana hati. Internalizing problems 
berfokus pada komponen emosional seperti kesedihan, rasa bersalah, kekhawatiran, dan lebih khususnya gangguan depresi dan kecemasan (Graber \& Sontag, 2009).

Internalizing problems termasuk kecemasan, depresi, gangguan obsesif-kompulsif, trauma, peristiwa yang menyakitkan seperti isolasi dan kesepian dapat menciptakan ketidaknyamanan seseorang yang mampu dimanifestasikan oleh perilaku internal lainnya (Merrel, 2008). Gejala ini berkesinambungan yang dapat diekspresikan dalam perilaku internal maupun eksternal seperti agresif, isolasi dari orang lain, dan perilaku menyimpang lainnya. Aspek Internalizing problems dibagi menjadi dua, yaitu 1) emotional problem atau masalah emosi yang termasuk gangguan kecemasan, gejala depresi, somatik, tidak bahagia, dan merasa bergantung kepada orang lain (2) peer problems yang berkaitan dengan individu dengan permasalahan dengan teman sebayanya seperti perlakuan bullying, berada lingkungan yang mengedepankan popularitas (Goodman, Lamping, \& Ploubidis, 2010).

Berbicara mengenai emosi, seorang remaja akan mengalami puncak dari perkembangan emosi (Fitri \& Adelya, 2017). Karena itu remaja cenderung meledak-ledak atau tidak mampu melakukan kontrol emosi sebagai tanda adanya ketidakstabilan emosi (Kusumastuti \& Mastuti, 2019). Depresi, kecemasan, dan internalizing problems pada remaja meningkat selama dua atau tiga dekade terakhir namun masih sedikit perhatian yang diberikan. Istilah internalisasi ini menunjukkan masalah yang dikembangkan dan dipelihara oleh seseorang sehingga dianggap "penyakit rahasia" sehingga sulit untuk dideteksi melalui pengamatan eksternal. Secara sederhana, seseorang yang menderita salah satunya dipengaruhi oleh masalah internalisasi yang berupa gejala, sindrom, atau gangguan yang terinternalisasi. (Merrell, 2008).

Salah satu yang menyebabkan internalizing problems adalah kesepian atau loneliness. Seperti penelitian yang dilakukan Yusuf (2016) yang mengungkapkan bahwa individu dengan depresi diprediksi oleh tingkat kesepian. Orang yang kesepian cenderung tidak terlalu menyenangkan, bahkan kesedihan dan keputusasaan sering ditampakkan dalam sikap negatif terhadap orang lain (Miller, 2018). Remaja sangat rentan mengalami kesepian, kecemasan sosial, dan gejala depresi. Hal ini termasuk internalizing problems yang sering terjadi bersama meski belum jelas bagaimana keterkaitannya (Danneel et al., 2019).

Pada dasarnya setiap orang pernah merasakan kesepian khususnya remaja meskipun dalam aktivitas yang sibuk (Bian \& Leung, 2015). Loneliness atau kesepian adalah salah satu keadaan yang melekat pada kondisi manusia (Febriani, 2021). Keadaan ini merupakan respon sebuah ketidakhadiran orang lain yang diinginkan oleh seseorang (Nurdiani, 2014). Terdapat lima bentuk spesifik loneliness, (1) loneliness of the inner self, yaitu merasa dirinya asing dengan kepribadian aslinya, (2) physical loneliness, yaitu merasa kecewa saat kebutuhan dan kedekatan secara fisik dengan orang lain tidak terbutuhi, (3) emotional loneliness, yaitu merasa dikucilkan secara emosi sehingga merasa kesepian dan tidak ada kelekatan dalam hubungan, (4) social loneliness, merasa dikucilkan oleh lingkungan sosial karena tidak adanya keterlibatan dengan lingkungan sosialnya, (5) spiritual loneliness, yaitu merasa hampa saat tujuan hidup yang tidak dapat terpenuhi (Astuti, 2019).

Kesepian seringkali dianggap hanya sementara, tetapi dapat berdampak Panjang, padahal kesepian akan dirasakan sepanjang perjalanan hidup seseorang, seperti saat masuk perguruan tinggi, saat adanya perubahan identitas dan hubungan di usia dewasa awal serta merasa kesepian disaat usia lanjut (Brehm, Miller, Perlman, \& Campbell, 2002). Kesepian yang dimiliki individu akan berdampak pada kesehatan fisik dan non fisik (Siwi \& Qomaruddin, 2021). Secara detail dalam Buku Loneliness: Human Nature and The Need for Social Connection juga menjelaskan dampak dari kesepian, yaitu (1) kesepian mempersulit orang untuk mengatur diri sendirian mengarah pada kebiasaan merusak diri. Kesepian melemahkan kemauan dan ketekunan 
sehingga cenderung melakukan perilaku yang merusak kesehatan mereka. (2) orang yang kesepian cenderung menarik diri. (3) tes menunjukkan bahwa kesepian mempengaruhi kekebalan dan sistem kardiovaskular. Orang yang kesepian mengalami lebih banyak kesulitan tidur (Griffin, 2010). Ketika seseorang merasa kesepian, ia cenderung merasa tidak puas, kehilangan, dan tertekan (Brehm, Miller, Perlman, \& Campbell, 2002). Depresi dan kesepian adalah peristiwa internalisasi yang tidak ditangani akan mengaktifkan perilaku dan gangguan eksternal (Morrow et al., 2006). Bahkan dampak semakin tingginya tingkat loneliness seseorang akan memunculkan kemungkinan untuk ide bunuh diri (Astuti, 2019). Penelitian ini bertujuan untuk mengetahui bagaimana hubungan loneliness dan Internalizing problems. Diharapkan mampu memberi informasi tambahan mengenai loneliness dan Internalizing problems pada remaja. Hipotesis penelitian ini adalah adanya hubungan positif antara loneliness dan internalizing problems. Semakin positif loneliness maka semakin tinggi internalizing problems yang dimiliki seorang remaja dan sebaliknya.

\section{METODE}

Penelitian ini merupakan penelitian kuantitatif korelasional. Subjek penelitian ini adalah remaja berusia 15-18 tahun yang menjadi siswa/siswi SMA di Jawa Timur dengan jumlah 616 orang. Teknik pengambilan sampel menggunakan teknik simple random sampling, dengan bantuan random.org. Hasil dari pengacakan sampel terpilih 4 kabupaten//kota di jawa Timur yaitu Gresik, Lamongan , dan Sidoarjo, dan Surabaya. Kemudian terpilih sekolah dari tiap kabupaten/kota yaitu 2 SMA Muhammadiyah di tiap kabupaten Gresik, Lamongan, dan Sidoarjo dan 3 sekolah di kota Surabaya.

Penelitian ini menggunakan dua instrumen. Pertama, menggunakan instrumen UCLA Loneliness Scale Version 3 yang dikembangkan oleh Russel, D. W (1996) dan diadaptasi oleh Nursyahrurahmah (2018) dengan hasil uji reliabilitas $\alpha=0,88$ yang terdiri dari 3 aspek dan berjumlah 20 item. Aspek pertama adalah personality, memiliki 3 item favorable dan 2 item unfavorable, contoh pernyatannya "Saya sering merasa kesepian", aspek kedua adalah Social Desirability, memiliki 3 item favorable dan 5 unfavorable, contoh pernyataannya "Saya merasa cocok dengan orang sekitar saya", aspek ketiga adalah depression memiliki 5 item favorable dan 2 item unfavorable, contoh pernyataannya "Saya merasa ada orang yang benar-benar mengerti saya." Instrumen ini menggunakan skala likert yang terdiri dari empat pilihan jawaban, yaitu "sangat setuju" diberi skor 4, "setuju" diberi skor 3, "tidak setuju" diberi skor 2, dan "sangat tidak setuju" diberi skor 1 bagi item favorable sedangkan "sangat setuju" diberi skor 1, "setuju" diberi skor 2, "tidak setuju" diberi skor 3, dan "sangat tidak setuju" diberi skor 4 bagi item unfavorable.

Kedua, menggunakan intrumen Strength \& Difficulties Questionnaire (SDQ) yang dikembangkan oleh Goodman (1997) dan telah diadaptasi oleh Wiguna (2010) dengan hasil uji reliabilitas $\alpha=0,773$. Instrumen ini terdiri dari 25 item yang dikelompokkan menjadi lima aspek yaitu, emotional problems, peer problem untuk mengukur Internalizing problems, conduct problem, hyperactivity, prosocial untuk mengukur externalizing problems. Contoh pernyataannya "Saya sering sakit kepala, sakit perut atau macam-macam sakit lainnya", Instrumen ini menggunakan skala likert dengan tiga pilihan jawaban, yaitu "benar dengan skor 0 " "agak benar dengan skor 1," dan "tidak benar dengan skor 2." 


\section{HASIL}

Penelitian yang telah dilakukan untuk mengetahui hubungan antara Loneliness dan Internalizing Problems pada remaja dengan rincian berikut:

Tabel 1.

Data Demografi

\begin{tabular}{lcc}
\hline \multicolumn{1}{c}{ Demografi } & $\begin{array}{c}\text { Laki-laki } \\
\mathbf{N = 2 1 7}(\mathbf{3 5 \%})\end{array}$ & $\begin{array}{c}\text { Perempuan } \\
\mathbf{N = 3 9 9}(\mathbf{6 5 \%})\end{array}$ \\
\hline Usia & 136 & 278 \\
15-16 Tahun & 81 & 121 \\
17-18 Tahun & & \\
\hline Domisili & 33 & 75 \\
Gresik & 41 & 79 \\
Lamongan & 30 & 76 \\
Sidoarjo & 113 & 169 \\
Surabaya & & \\
\hline Internalizing Problems & 90 & 98 \\
Normal & 106 & 211 \\
Borderline & 21 & 90 \\
Abnormal & & \\
\hline Loneliness & 0 & 118 \\
Rendah & 63 & 281 \\
Sedang & 154 & \\
Tinggi & & \\
\hline
\end{tabular}

Penelitian ini berjumlah 616 orang responden dengan rincian 217 laki-laki dan 399 perempuan. Responden berada di Jawa Timur dengan sebaran responden berdomisili di kota Gresik, Lamongan, Sidoarjo, dan Surabaya. Berdasarkan data demografi dan kategori yang telah didapatkan hasil dengan melihat kategori Internalizing Problems, responden laki-laki memiliki jumlah 90 orang dengan kategori normal yang dimana berarti tidak ada gangguan berjumlah 106 orang dengan kategori borderline yang berarti terdapat indikasi gangguan dan 21 orang dengan kategori abnormal yang berarti terdapat gangguan. Sedangkan pada responden perempuan didapatkan hasil 98 orang dengan kategori normal, 211 orang dengan kategori borderline, dan 90 orang dengan kategori abnormal. Selanjutnya didapatkan hasil dengan melihat kategori Loneliness, responden perempuan memiliki jumlah 118 orang dengan kategori sedang dan 281 orang dengan kategori tinggi. Sedangkan responden laki-laki memiliki jumlah 63 orang dengan kategori sedang dan 154 orang dengan kategori tinggi.

Uji Normalitas dilakukan menggunakan uji Kolmogorov-Smirnov. Sedangkan pada Uji Linearitas antara variabel internalizing problems dan loneliness mendapatkan hasil Deviation from Linearity sebesar 0,807 yang berarti variabel internalizing problems dan loneliness memiliki data yang linear karena $0,807>0,05$. Selanjutnya uji hipotesis dilakukan menggunakan Uji Korelasi Pearson. Berikut tabel uji analisis yang telah didapatkan: 
Tabel 2.

Uji Korelasi

\begin{tabular}{lcc}
\hline Variabel & Koefisien Korelasi (r) & Sig (p) \\
\hline Internalizing-Loneliness & 0,618 & 0,001 \\
\hline${ }^{*} p<0,05$ & &
\end{tabular}

Berdasarkan tabel 2. Uji Korelasi dapat disumpulkan bahwa adanya hubungan positif yang signifikan antara variabel Loneliness (X) dan variabel Internalizing Problems (Y) ditandai dengan nilai sig (1-tailed) sebesar 0,001 $(<0,05)$ yang berarti signifikan dan nilai Pearson Correlation sebesar 0,618 yang berarti semakin tinggi tingkat Loneliness pada seseorang maka semakin tinggi pula tingkat Internalizing Problems yang dimilikinya.

\section{DISKUSI}

Temuan penelitian ini menunjukkan bahwa hipotesis penelitian diterima, loneliness dapat memprediksi internalizing problems pada individu. Hal ini juga sejalan dengan penelitian yang dilakukan Blossom dan Apsche (2013) bahwa terdapat kaitan antara loneliness dengan internalizing problems, dimana loneliness dapat menciptakan ketidaknyaman yang terinternalisasi sehingga dimanifestasikan ke dalam gejala internalizing problems seperti sedih, khawatir, atau merenung. Hal senada juga di sampaikan oleh Morrow et al., (2006) bahwa dampak dari kesepian dapat menciptakan perasaan yang tidak nyaman, seperti khawatir, sedih, merenung, bahkan sampai perilaku agresif, dan mengisolasi diri dari orang lain. Pendapat ini kembali ditegaskan oleh Winkel (2017) bahwa loneliness diikuti oleh penilaian negatif yang membuat seseorang menarik diri, dimana perilaku ini merupakan gejala dari Internalizing problems (Ediati, 2015).

Loneliness terjadi karena seseorang yang tidak mampu membentuk hubungan sosial dengan orang lain dan merasa tidak ada yang bisa memahaminya sehingga menunjukkan gejala internalizing problems seperti gejala depresi. Seperti yang dijelaskan oleh Erzen dan Çikrikci (2018) loneliness memiliki efek signifikan pada depresi, yang di tandai dengan suasana hati yang sedih, kehilangan minat, gangguan tidur, keluhan somatik, hingga pesimisme (APA, 2013).

Selanjutnya dijelaskan pula oleh Goossens (2018) bahwa kesepian dapat mengganggu seseorang dalam berinteraksi dengan orang lain karena merasakan kekhawatiran ditolak oleh orang lain. Loneliness juga terjadi karena tidak adanya dukungan dari orang sekitarnya seperti teman sekelas, guru ataupun lingkungan sekolah. Hal ini sejalan dengan dengan penjelasan Santini et al., (2021) bahwa remaja yang tidak mendapat dukungan dari guru maupun teman sekolah dapat merasa kesepian yang menimbulkan masalah internalizing problems seperti gejala depresi, kecemasan, stres. Hal ini terjadi karena seseorang tidak mampu membentuk hubungan dengan orang lain sehingga terjadi social connectedness atau keterputusan sosial dan muncul simtom internalizing problems.

Kesepian pada remaja terjadi karena adanya perubahan kondisi yang tidak diinginkan sehingga menyebabkan kecemasan sosial sebagai bentuk dari internalizing problems. Kesepian ini sangat rentan dirasakan oleh usia remaja (Danneel et al., 2019). Seseorang yang memiliki kemampuan menyesuaikan diri dengan lingkungannya akan menunjukkan ketercapaian tugas perkembangannya. Hal ini sebagai upaya seseorang dalam mencapai keharmonisan, kebahagiaan, dan menjadi orang yang produktif (Yanizon, 2016). Jika seseorang tidak dapat beradaptasi dengan baik maka kehidupan sosialnya akan bermasalah dan cenderung menarik diri dari lingkungannya. Seseorang menarik diri karena memiliki ketidakpercayaan terhadap 
orang lain, memiliki kelemahan dalam berkomunikasi dan cenderung fokus dengan kegiatannya masing-masing (Suwarni \& Rahayu, 2020). Kondisi ini akan memicu munculnya gejala kecemasan sosial yang ditandai dengan pikiran negatif dan tidak realistis, serangan panik, serta melakukan perilaku kompulsif sebagai bentuk penginternalisasian masalah ke dalam dirinya. Seseorang yang kesepian sering mengalami kecemasan sosial. Baik kesepian maupun kecemasan sosial dianggap sebagi bentuk negatif dari sikap terhadap orang lain karena menunjukkan sikap yang pasif dan tidak reseponsif (Misnani, 2016).

Menghabiskan waktu sendiri belum tentu merasa kesepian. Begitu pun menghabiskan waktu banyak dengan orang lain belum tentu perasaan kesepian itu tidak ada. Maes (2019) juga menjelaskan bahwa menghabiskan waktu sendirian tidak menentukan kualitas dan kuantitas hubungan seseorang dengan orang lain. Remaja memilih menghabiskan waktu sendirian sebagai tujuan refleksi diri, pengaturan diri, dan melakukan kegiatan yang mengasah kreativitas (Danneel et al., 2017). Dengan demikian loneliness pada remaja menjadi salah satu masalah yang sulit terdeteksi secara langsung (Merrel, 2008). Hal ini dapat menjadi informasi bagi usia remaja dan acuan penelitian selanjutnya. Penelitian ini menjadi gambaran bahwa remaja dapat menginternalisasikan masalah dikarenakan adanya perasaan kesepian. Namun, kekurangan penelitian ini yaitu peneliti hanya berfokus meneliti dua variabel sehingga masih memerlukan penelitian lebih lanjut dengan variabel tambahan lainnya.

\section{KESIMPULAN}

Berdasarkan hasil penelitian yang diperoleh menunjukkan hipotesis dapat diterima Hasil menunjukkan bahwa semakin tinggi seseorang yang merasa kesepian akan semakin tinggi pula untuk menginternalisasikan masalah ke dalam dirinya. Implikasi dari penelitian ini adalah remaja diharapkan melakukan langkah preventif agar tidak merasakan kesepian secara berkepanjangan. Perasaan kesepian merupakan salah satu masalah emosi yang subjektif dan jarang diketahui dasar penyebabnya namun jika terus dibiarkan akan memiliki dampak yang cukup buruk baik kesehatan fisik maupun psikis, terutama bagi remaja yang rentan mengalami kesepian. Salah satu caranya adalah mampu beradaptasi dan lebih percaya diri untuk melakukan interaksi sosial di lingkungan sekitar. Kemudian, untuk peneliti selanjutnya diharapkan dapat lebih mengkaji terkait Loneliness dan Internalizing Problems pada remaja dengan tambahan variabel.

\section{DAFTAR PUSTAKA}

Astuti, Y. D. (2019). Kesepian dan Ide Bunuh Diri di Kalangan Tenaga Kerja Indonesia. Psikologika: Jurnal Pemikiran Dan Penelitian Psikologi, 24(1), 35-58. https://doi.org/10.20885/psikologi.vol24.iss1.art4

Bian, M., \& Leung, L. (2014). Linking loneliness, shyness, smartphone addiction symptoms, and patterns of smartphone use to social capital. Social Science Computer Review, 6179. DOI: https://doi.org/10.1177\%2F0894439314528779

Blossom, P., \& Apsche, J. (2013). Effects of Loneliness on Human Development. International Journal of Behavioral Consultation and Therapy, 28-29

Brehm, S. S., Miller, R. S., Perlman, D., \& Campbell, S. M. (2002). Intimate Relationship Third Edition. New York: McGraw-Hill. 
Danneel, S., Maes, M., Vanhalst, J., Bijttebier, P., \& Goossens, L. (2017). Developmental Change in Loneliness and Attitudes Toward Aloneness in Adolescence. Journal of Youth and Adolescence, 47(1), 148-161. https://doi.org/10.1007/s10964-017-0685-5

Danneel, S., Nelemans, S., Spithoven, A., Bastin, M., Bijttebier, P., Colpin, H., Van Den Noortgate, W., Van Leeuwen, K., Verschueren, K., \& Goossens, L. (2019). Internalizing Problems in Adolescence: Linking Loneliness, Social Anxiety Symptoms, and Depressive Symptoms Over Time. Journal of Abnormal Child Psychology, 47(10), 1691-1705. https://doi.org/10.1007/s10802-019-00539-0

Erzen, E., \& Çikrikci, Ö. (2018). The effect of loneliness on depression: A meta-analysis. International Journal of Social Psychiatry, 64(5), 427-435. https://doi.org/10.1177/0020764018776349

Fitri, N. F., \& Adelya, B. (2017). Kematangan emosi remaja dalam pengentasan masalah. $\begin{array}{llll}\text { Jurnal Penelitian } & \text { Guru 2(2), 30-39. }\end{array}$ https://jurnal.iicet.org/index.php/jpgi/article/view/225

Febriani, Z. (2021). Perbedaan Tingkat Kesepian pada Remaja Ditinjau dari Jenis Kelamin. Jurnal Pendidikan Tambusai, 7032-7037.

Goodman, A., Lamping, D. L., \& Ploubidis, G. B. (2010). When to use boader internalising and externalising subscales instead of the hypothesised five subscales on the strengths and difficulties questionnaire (SDQ): data from british parents, teachers and children. $J$ Abnorm Child Psychol.

Goossens, L. (2018). Loneliness in Adolescence: Insights From Cacioppo's Evolutionary Model. Child Development Perspectives, 12(4), 230-234. https://doi.org/10.1111/cdep.12291

Goodman, R. (1997). The strengths and difficulties questionnaire: a research note. Journal of Child Psychology and Psychiatry, 581-586.

Graber, J. A., \& Sontag, L. M. (2009). Internalizing Problems During Adolescence. Handbook of Adolescent Psychology, 642-682.

Griffin, J. (2010). The Lonely Society. Mental Health Foundation.

Kusumastuti, D., \& Mastuti, E. (2019). Hubungan Antara Persepsi Keterlibatan Ayah Dalam Pengasuhan Dan Kematangan Emosi Pada Remaja. Jurnal Psikologi Pendidikan Dan Perkembangan, 8, 10-20.

Maes, M., Qualter, P., Vanhalst, J., Van den Noortgate, W., \& Goossens, L. (2019). Gender Differences in Loneliness Across the Lifespan: A Meta-Analysis. European Journal of Personality, 33(6), 642-654. https://doi.org/10.1002/per.2220

Merrell, K. W. (2008). Helping Students Overcome Depression and Anxiety. New York: Guilford Press.

Miller, R. S. (2018). Intimate Relationships. New York: McGraw-Hill Education.

Misnani, J. (2016). Hubungan Perilaku Asertif dan Kesepian dengan Kecemasan Sosial Korban Bullying Pada Siswa. Psikoborneo, 4(4), 516-521. https://media.neliti.com/media/publications/129183-ID-perilaku-asertif-dankecenderungan-kenak.pdf

Morrow, M. T., Hubbard, J. A., Dearing, K. F., McAuliffe, M. D., \& Rubin, R. M. (2006). Childhood aggression, depressive symptoms, and peer rejection: The mediational model revisited. International Journal of Behavioral Development, 30(3), 240-248. https://doi.org/10.1177/0165025406066757

Nurdiani, A. F. (2014). Uji Validitas Konstruk Alat ukur Ucla Loneliness Scale Version 3. Jurnal Pengukuran Psikologi dan Pendidikan Indonesia, 377-391. 
Nursyahrurahmah. (2018). Hubungan kelekatan teman sebaya terhadap kesepian dimediasi oleh kompetensi sosial remaja. Tesis. Program Pascasarjana Universitas Muhammadiyah Malang, Malang

Russel, D. W. (1996). UCLA loneliness scale (version 3): reliability, validity, and factor structure. Journal of Personality Assesment, 20-40.

Santrock, J. W. (2011). Life Span Development. Jakarta: Erlangga.

Santini, Z. I., Pisinger, V. S. C., Nielsen, L., Madsen, K. R., Nelausen, M. K., Koyanagi, A., Koushede, V., Roffey, S., Thygesen, L. C., \& Meilstrup, C. (2021). Social Disconnectedness, Loneliness, and Mental Health Among Adolescents in Danish High Schools: A Nationwide Cross-Sectional Study. Frontiers in Behavioral Neuroscience, 15(April). https://doi.org/10.3389/fnbeh.2021.632906

Scaini, S., Palmiera, S., \& Caputi, M. (2018). The Relationship Between Parenting and Internalizing Problems in Childhood. Parenting-Empirical Advances and Intervention Resources, 87-100.

Siwi, L. G., \& Qomaruddin, M. B. (2021). Perasaan kesepian berhubungan dengan depresi, kecemasan, dan stres pada siswa SMA. Jurnal Ilmiah Permas: Jurnal Ilmiah STIKES Kendal, 739-746.

Suwarni, S., \& Rahayu, D. A. (2020). Peningkatan Kemampuan Interaksi Pada Pasien Isolasi Sosial Dengan Penerapan Terapi Aktivitas Kelompok Sosialisasi Sesi 1-3. Ners Muda, 1(1), 11. https://doi.org/10.26714/nm.v1i1.5482

Swatrz, S. G. (2012). Child and Adolescent Development: A South African Sociocultural Pespective. Oxford: Oxford University Press.

van Winkel, M., Wichers, M., Collip, D., Jacobs, N., Derom, C., Thiery, E., Myin-Germeys, I., \& Peeters, F. (2017). Unraveling the Role of Loneliness in Depression: The Relationship Between Daily Life Experience and Behavior. Psychiatry (New York), 80(2), 104-117. https://doi.org/10.1080/00332747.2016.1256143

Wiguna, T., Kris, P. S., Pamela, C., Rheza, A. M., \& Hapsari, W. A. (2010). Masalah emosi dan perilaku pada anak dan remaja di poliklinik jiwa anak dan remaja RSUPN dr. Ciptomangunkusumo (RSCM), Jakarta. Sari Pedatri, 270-277.

Yanizon, A. (2016). Description of The Social Adjustment of Students In Madrasah Aliyah 1 Curup. KOPASTA: Jurnal Program Studi Bimbingan Konseling, 3(1), 1-8. https://doi.org/10.33373/kop.v3i1.260

Yusuf, N. P. (2016). Hubungan Harga Diri dan Kesepian dengan Depresi pada Remaja. Psychology Forum UMM, 386-393. 